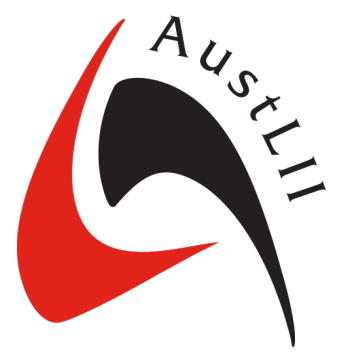

www.austlii.edu.au

\section{Australasian Legal Information Institute}

A joint facility of UTS and UNSW Faculties of Law

Level 14, 61 Broadway, Ultimo NSW 2007

PO Box 123 Broadway NSW 2007

Tel: +61295144921

Fax: +61295144908

Email: feedback@austlii.edu.au

\title{
The Australian Data Strategy and Legal Information (AustLII Submission on the ADS Discussion Paper)
}

As Co-founders and Co-Directors of the Australasian Legal Information Institute (AustLII), we appreciate the opportunity to provide feedback on the proposed Australian Data Strategy. ${ }^{1}$ As requested, we address below the seven questions set out in the Discussion Paper.

This submission focusses on the role of legal information in the Australian Data Strategy, with additional comments on issues which we think are of particular importance, such as data privacy. We have taken into account the joint submission of AllensHub/AUSCL/uDASH ('Allens Hub Submission'), and at various places endorse aspects of that submission rather than repeating the details.

\section{AustLII: Background and objectives}

The Australasian Legal Information Institute (AustLII - https://www.austlii.edu.au) is Australia's most-used online free-access resource for Australian legal information. AustLII serves about 238 million page access requests annually (about 700,000 daily) from over 6.5 million distinct hosts. AustLII provides critical national research infrastructure that underpins all research that deals directly or indirectly with Australian law. It also helps ensure that the legal system operates effectively and efficiently, supports access to justice and helps to enable the rule of law for Australia and internationally.

Established in 1995 as a joint facility of the faculties of law at UTS and UNSW, AustLII aims to be a comprehensive free access source of Australasian legal information. AustLII maintains extensive data provision agreements with government, courts, educational institutions and businesses, with jurisdictional breadth and historical depth. It provides an integrated framework of primary and secondary content, with tools and services to support

1 See Discussion Paper: Australian Data Strategy on 'Australia's Digital Economy' website < $\underline{\text { https:// }}$ digitaleconomy.pmc.gov.au/fact-sheets/data-and-digital-economy> 
The Australian Data Strategy and Legal Information (AustLII Submission)

the legal information and research needs of the many different communities who access its resources. These include:

- Nearly 900 free access databases of Australasian legal information, including: comprehensive legislation and related materials from all jurisdictions (past and present); case law from most courts, tribunals and regulators (past and present); the text of all treaties to which Australia is a party; Australia's largest collection of law journals, law reform reports and judicial scholarship; aggregated subject specific collections and thematic libraries; collaboratively developed plain language law handbooks, legal texts and educational resources (AustLII Communities).

- AustLII automates insertion of millions of hypertext links integrating legislation, case law and commentary, and was the pioneer of such innovative data services in Australia.

- LawCite is the only free access international citator for cases and journal articles, automatically indexing and data mining millions of documents on AustLII and collaborating LIIs from around the common law world. This is 'big data' at its best.

- DataLex, AustLII's legal reasoning application development platform enables creation of legal advice and decision-making apps, and 'Rules as Code' development. It is the basis of AustLII's future strategy for comprehensive free provision of AI-based legal resources.

Australia's national legal information infrastructure is provided by AustLII, to a much greater extent than by any government-provided legal data service. AustLII created free access to law in Australia, and is still its leader.

AustLII advocates for policies supporting free access to legal information, and the development of a commons of AI-based legal utilities. AustLII's Data Strategy seeks to expand the scope and utility of legal information freely available to the Australian community.

\section{Answers to Questions posed in Discussion Paper}

\section{To what extent do you agree that the outline of the Australian Data Strategy covers the right issues?}

We interpret an 'Australian' data strategy to require a 'national' data strategy, not a 'Commonwealth Government' data strategy, so some steps that the Commonwealth will need to take will include legislation affecting the private sector and data it controls, and other steps will require obtaining cooperation from the States and Territories. The Strategy should put this up front, and it does not do so at present.

Appendix 2 ('Principles' and 'Strategy Shell') is unfortunately too vague to be of any use, and not worth commenting on except that data privacy is not kept sufficiently distinct from 'trust' and 'security', with which it is not identical.

As the Allens' Hub Submission suggests (Question 5(ii)), the question is not one of public 'trust', but rather whether our public institutions and their systems for handing data are 
The Australian Data Strategy and Legal Information (AustLII Submission)

'trustworthy'. This is particularly so when it comes to personal data, where there are far too many reasons why such trust is lacking at present, ranging from the maladministration and misuse of automated systems (RoboDebt), the misleading explanations of the IT failures leading to CensusFail, ${ }^{2}$ the reneging and vacillation on the opt-in/opt-out basis of My Health Record, ${ }^{3}$ the disastrous privacy invasions in the public release of supposedly 'anonymised' Medicare and PBS data, ${ }^{4}$ and the 'shoot the messenger' legislative overkill that followed, 5 to mention but a few. The Commonwealth government cannot assume public trust in relation to personal data involved in IT projects, it has to earn it from a starting point of a significant sector of the public having no such trust.

\section{What key areas or issues are missing? Why are they key issues?}

Removal of existing monopolies over data which should be key public assets, in both the private sector and the public sector, is missing as a key issue. So is the regulation of AI. See later under Question 4.

\section{Are the issues below considered important to your organisation; and if so why?}

Yes, all of these issues are very important to AustLII, for reasons explained below.

\section{a. Ethical and transparent use of data}

The Australian public relies on AustLII for free access to its most comprehensive source of information on Australia's law and legal system. It relies upon AustLII publishing legal information free of external influences or biases, as comprehensive as possible, and transparent in its timeliness (see 'Update Status' on landing page). Australia's courts, tribunals, legislatures and government agencies rely upon AustLII to provide to the public the legal information that they create, in ways which are accurate, timely, and reliable. AustLII's publication processes are, and must be, transparent to those organisations. Researchers who wish to use AustLII data must comply with AustLII's requirements for ethical use of data, particularly identified court decisions.

\footnotetext{
2 J. Taylor "Censusfail' hangs over Australian Bureau of Statistics as it prepares for 2021 survey' The Guardian 11 July $2021<$ https://www.theguardian.com/australia-news/2021/jul/11/censusfail-hangs-over-australianbureau-of-statistics-as-it-prepares-for-2021-survey $>$
}

\footnotetext{
${ }^{3}$ L. Minion 'Technical chaos and privacy backlash as My Health Record opt out period begins' HealthCare IT News 16 July 2018 <https:/www.healthcareit.com.au/article/technical-chaos-and-privacy-backlash-my-healthrecord-opt-out-period-begins $>$; For current position, see Australian Digital Health Agency 'Stronger My Health Record privacy laws' <https://www.myhealthrecord.gov.au/about/legislation-and-governance/summary-privacyprotections $>$

4 See OAIC 'MBS/PBS data publication' 23 March $2018<\underline{\text { https://www.oaic.gov.au/privacy/privacy-decisions/ }}$ investigation-reports/mbspbs-data-publication/ >

5 J. Taylor 'Melbourne professor quits after health department pressures her over data breach' The Guardian, 8 March $2020<$ https://www.theguardian.com/australia-news/2020/mar/08/melbourne-professor-quits-after-healthdepartment-pressures-her-over-data-breach>
} 
The Australian Data Strategy and Legal Information (AustLII Submission)

\section{b. Data security}

The reliance of courts, the public sector, the legal system and the public on AustLII as the most-accessed online legal service in Australia means that it is essential national infrastructure, so the maintenance of AustLII's cyber-security is of national importance.

\section{c. Data privacy}

AustLII has always had to balance the needs of Australia's system of 'Open Justice' with the desire of those involved in the justice system to protect their privacy. The protection of case law on AustLII against its use for the purposes of surveillance capitalism continues as a priority. Stronger data privacy laws, which also respect and support the 'Open Justice' requirements, are desirable.

A more general issue with the Strategy is the references to data as a 'commodity', without noting that personal data is not a commodity, it is the subject matter of human rights. Australia's Data Strategy should explicitly reject the surveillance capitalist position that personal data is a commodity.

\section{d. Data innovation}

AustLII has been based on data innovations throughout its history since 1995. For the period to 2025, and for some years beyond, many of AustLII's future innovations will be based on the use of AI technologies that AustLII has developed (the yscript language and DataLex infrastructure) to transform its near comprehensive collection of legislation, case law and other legal source documents by complementing them with interactive forms such as 'Rules as Code', document generators, linked open data, and data visualisations. Other technologies and innovative tools will support the changing and expanding nature of legal information, the changing needs of users, and the capacity to use legal data in more creative and sophisticated forms. Examples are provision of more secure and authoritative data, and virtual secure data labs to allow analysis of sensitive data sets.

\section{e. Accessible data/open data}

Since 1995, one of AustLII's principles has been that public legal information should be available on free and equal terms for republication, from the institutions that create it (courts, legislation offices etc). So that this is fair to late entrants, such institutions should maintain back-sets (archives) of their publications. This makes other repositories unnecessary, and republishers such as AustLII should not also be expected to be repositories. ${ }^{6}$

\section{f. Data sharing for improved services}

This is covered in (e) above, insofar as legal data is concerned.

\footnotetext{
6 See Part 4 of G. Greenleaf, A. Mowbray and P. Chung, 'The Meaning of 'Free Access to Legal Information': A Twenty Year Evolution' Journal of Open Access Law (JOAL), Issue 1, 2013, <https://ssrn.com/ $\underline{\text { abstract }=2158868>}$
} 
The Australian Data Strategy and Legal Information (AustLII Submission)

4. What are the top three outcomes from the Australian Data Strategy you would like to see by 2025 ?

By 2025 AustLII would like to see the following outcomes achieved:

(i) Undo data monopolies - There are three main impediments to the full realisation of a free access legal data commons in Australia:

(a) For many superior court decisions in Australia (mainly State courts), there is a gap of about 30 years prior to AustLII's formation in 1995, where commercial legal publishers have a monopoly over the texts of the decisions of those courts, because of copyright law. These court decisions should not have copyright protection, as is the case in most other countries. ${ }^{7}$ These decisions are essential to the development of future innovations in case law, because of the system of precedent. ${ }^{8}$

(b) The official status of online legislation is now common in Australian jurisdictions, but this official status, and the ability of others to rely upon it, is lost once the legislation is republished by 'downstream' publishers like AustLII. This monopoly over official status is unnecessary, because of innovations such as digital signatures and date stamping, and should be removed to enable competition in the provision of legislation. ${ }^{9}$

(c) Standards are an essential part of the legal system, but Australian Standards cannot be republished for free access and development of innovations. This should be reformed, at least in relation to Standards the use of which is required by legislation. An alternative revenue stream should be developed for Standards Australia, as AustLII has previously argued. ${ }^{10}$ Standards Australia has plans to make standards available for non-commercial access by 2023.11

(ii) Reform data privacy - Australia's Privacy Act should be reformed to meet the highest international standard, currently that of the EU's General Data Protection Regulation (GDPR), including recognition as 'adequate protection' under the GDPR, and should

\footnotetext{
7 See G. Greenleaf and D. Lindsay Public Rights: Copyright's Public Domains (Cambridge University Press, 2018), pp. 221-226.

8 There is a related monopoly issue concerning 'authorised reports', but it is of declining importance as they become less relevant: see Chung, Mowbray and Greenleaf 'Authority and integrity of primary legal sources' AustLII, 2 March 2015<http://www.austlii.edu.au/austlii/announce/2015/2.pdf>

9 See Greenleaf, Mowbray and Chung ‘The Meaning of Free Access to Law’, op cit, pp. 21-22.

10 P. Chung, G. Greenleaf, and A. Mowbray 'The Need for Free Access to Regulated Standards (Submission by AustLII to Standards Australia in Response to Its Discussion Paper, July 2019 'Distribution and Licensing Policy Framework') (July 26, 2019). UNSW Law Research Paper No. 19-64<https://ssrn.com/ $\underline{\text { abstract }=3422586>}$.

11 See Standards Australia Distribution and Licensing Policy Framework, November 2019, p. $9<\underline{\text { https:// }}$ www.standards.org.au/StandardAU/Media/attachment/media\%20release/Standards-Australia-Distribution-andLicensing-Policy.pdf>
} 
The Australian Data Strategy and Legal Information (AustLII Submission)

enact a complementary 'serious invasions of privacy' statutory action. ${ }^{12}$ Australia should then become a party to the global data protection Convention 108. Australia should become a leader in data privacy rather than a laggard.

(iii) Legislate for ethical AI - The AI Action Plan announced in the Budget lacks any commitment to legislate to regulate AI. Without a clear ethical framework for AI development, Australian AI innovations will pose considerable risks to Australian citizens, and may also find that they are internationally non-competitive as the international environment moves toward regulation. The European Commission's proposal for a Regulation on Artificial Intelligence (also described as an 'AI Act') ${ }^{13}$ is likely to become pivotal in the global regulation of artificial intelligence. By establishing demanding standards for what AI products may be provided into the EU or used there, it is possible that this will create a 'Brussels effect' which prompts the adoption of EU-modelled standards (de jure or de facto) globally. ${ }^{14}$ Australia's Human Rights Commission has made one of the first proposals for national legislation in its 2021 Human Rights and Technology Report ${ }^{15}$ which makes 23 recommendations for the regulation of AI, almost all involving legislation. These 'Australian principles' proposed to be legislated are only a small sub-set of those proposed by the EU, but it would not be surprising if there was some greater degree of convergence by the time both jurisdictions (and others) have completed their legislative processes. Australia should not become a laissez-faire backwater in relation to AI.

It is essential to keep these positions constant across all other aspect of the Australian Data Strategy, making sure that all elements are inter-related rather than explored in isolation. We endorse the Allens Hub Submission (Question 3) on the need for such integration.

\section{Do you have any other comments on the Australian Data Strategy?}

When the Strategy has more substance, it will be good if comments are again called for.

COVID-19 data sharing strategies are correctly emphasised in the Discussion Paper, noting that they involved 'navigating stringent legislative and privacy requirements', presumably a reference to the COVIDSafe Act, which is in fact the most privacy-protective legislation in Australia. However, the pandemic is not over, and the mechanisms of 'COVID surveillance' continue to grow beyond proximity tracking (COVIDSafe app) to attendance tracking ( $\mathrm{QR}$

12 G. Greenleaf “GDPR Creep' for Australian Businesses But Gap in Laws' (2018) 154 Privacy Laws \& Business International Report 1, 4-5, <https://ssrn.com/abstract=3226835>; K. Kemp and G. Greenleaf 'Competition and Consumer Watchdog Spurs Australian Privacy Changes' (2020) 167 Privacy Laws \& Business International Report 25-28 < $\underline{\text { https://ssrn.com/abstract=3748311 }>}$

13 European Commission Proposal for a Regulation of the European Parliament and of the Council Laying Down Harmonised Rules on Artificial Intelligence (Artificial Intelligence Act) and Amending Certain Union Legislative Acts, Brussels, 21.4.2021 COM (2021) 206 final

14 G. Greenleaf 'The 'Brussels effect' of the EU's 'AI Act' on data privacy outside Europe' (2021) 171 Privacy Laws \& Business International Report 1

15 Australian Human Rights Commission Human Rights and Technology Final Report (2021), plus summaries $<$ https://tech.humanrights.gov.au/downloads?mc_cid=f780633f2f\&mc_eid=5a2fe75aaf $>$ 
The Australian Data Strategy and Legal Information (AustLII Submission)

Codes) and will soon include various types of Status Certificates. But the legislative response has stalled, when what is needed is one piece of legislation (probably based on the COVIDSafe Act) to deal with all types of COVID surveillance. ${ }^{16}$

\section{How should the Government keep talking about data issues?}

The Allens Hub Submission makes good suggestions which we endorse, that when discussing data issues, Government should:

1. be concrete rather than abstract, and honest about strategic choices (for example between data privacy and data innovation);

2. frame the discussion as being about trustworthiness rather than (potentially blind) trust;

3. use clear and consistent terminology, including in legislation.'

We would add that being honest should include admitting past mistakes and addressing how they can be avoided in future.

7. How do you see your organisation interacting with the Australian Data Strategy? What guidance is important to you to help you achieve the actions set out in the Strategy?

AustLII looks forward to developments of substance coming from a more developed Strategy with which it can then interact. If existing impediments to access to key legal data are removed, this will be an incentive to AustLII to continue to develop innovations in the use of such data. AustLII would be happy to participate in further discussions to develop aspects of the Strategy.

Philip Chung, Associate Professor of Law, UNSW, and Executive Director, AustLII Andrew Mowbray, Professor of Law \& Information Technology, UTS, and Co-Director, AustLII

Graham Greenleaf AM, Professor of Law \& Information Systems, UNSW, Senior Researcher and Co-Founder, AustLII

(on behalf of the Australasian Legal Information Institute)

5 August 2021

16 G. Greenleaf and K. Kemp 'COVID \& Digital Surveillance: Common Legislative Protections for Proximity Apps, Attendance Tracking, and Status Certificates (Part II) (Presentation Slides)' UN Special Rapporteur on the Right to Privacy Session: 'COVID-19 and Privacy in Asia, Australasia and Europe' 23 June 2021 (Presentation)' $<\underline{\text { https://ssrn.com/abstract }=3875920}>$ 